\title{
Case report of a successful term pregnancy following renal transplantation
}

\author{
Prabhadevi Kodey $^{1}$, Badugu Rao Bahadur ${ }^{1 *}$, V. Srilatha ${ }^{2}$, G. Srinivasa Rao ${ }^{3}$, Sowjanya P. $^{1}$
}

${ }^{1}$ Department of Obstetrics and Gynaecology, ${ }^{2}$ Department of Nephrology, ${ }^{3}$ Department of Urology, NRI Medical College, Mangalagiri, Guntur, Andhra Pradesh, India

Received: 09 June 2019

Revised: 28 June 2019

Accepted: 03 July 2019

\section{*Correspondence:}

Dr. Badugu Rao Bahadur,

E-mail: drraobahadur@yahoo.com

Copyright: ( ) the author(s), publisher and licensee Medip Academy. This is an open-access article distributed under the terms of the Creative Commons Attribution Non-Commercial License, which permits unrestricted non-commercial use, distribution, and reproduction in any medium, provided the original work is properly cited.

\begin{abstract}
Pregnancy with renal disease is associated with high risk for both mother and fetus with adverse outcomes. Criteria for considering pregnancy in renal transplanted patients include good post-transplant health for 2 years, stable allograft function with a serum creatinine $<1.5 \mathrm{mg} / \mathrm{dl}$, absence of rejection, control of blood pressure, absence of proteinuria. Authors report a case of 26-year-old, primigravida had renal transplantation done in NRI Medical College and treated with immunosuppressive therapy with tablets Tacrolimus 1mg twice daily, Azathioprine 50mg twice daily, Prednisolone 10mg once daily and continued till delivery. Developed gestational hypertension treated with tablet Amlodipine 5mg once daily. Elective caesarean section done for contracted pelvis. Post-natal period was uneventful and discharged on immunosuppressive therapy and contraceptive advice. Post-renal transplantation pregnancy should have multidisciplinary approach for. With close medical and obstetric follow up, successful outcome for both mother and infant is possible.
\end{abstract}

Keywords: Creatinine, Immunosuppressive therapy, Pregnancy, Renal transplant

\section{INTRODUCTION}

Pregnancy with renal disease is associated with high risk of both mother and fetus with adverse outcomes. Pregnancy in a woman with kidney disease can increase risk for gestational hypertension, pre-eclampsia and eclampsia. Fetal risks include intrauterine growth restriction, preterm, still birth. Pregnancy following a kidney transplantation continues to remain challenging due to adverse effects of immunosuppressive medication, risk of deterioration of allograft function, risk of adverse maternal complications of preeclampsia and hypertension, and risk of adverse fetal outcomes of premature birth, low birth weight, and small for gestational age infants.
Criteria for considering pregnancy in renal transplanted patients include good post-transplant health for 2 years, stable allograft function with a serum creatinine $<1.5$ $\mathrm{mg} / \mathrm{dl}$, absence of rejection, control of blood pressure, absence of proteinuria. $^{1,2}$

\section{CASE REPORT}

A 26 year old, primigravida had successful renal transplantation in 2016 in NRI Hospital, for indication of chronic kidney disease stage. ${ }^{5}$ Following renal transplantation she had been on regular follow-up with nephrologist, and subsequently conceived spontaneously two years after renal transplantation. 
She had been on maintenance immunosuppressive therapy with tablets Tacrolimus 1mg twice daily, Azathioprine $50 \mathrm{mg}$ twice daily, and Prednisolone $10 \mathrm{mg}$ once daily at the time of conception and continued till delivery. She developed gestational hypertension from 6th month of pregnancy and was taking tablet Amlodipine $5 \mathrm{mg}$ once daily. Serial ultrasounds showed normal foetal growth pattern. Renal function tests, complete blood picture and complete urine analysis were done once in every 2 weeks (HB $8 \mathrm{gm} / \mathrm{dl}$, Serum Creatinine 1-1.4 $\mathrm{mg} / \mathrm{dl}$, serum urea within normal limits). ${ }^{3-9}$ She had lower urinary tract infection at 32 weeks of gestation and was treated with Tab. Cefuroxime $500 \mathrm{mg}$ twice daily for two weeks as per culture sensitivity report.

She was admitted at 37 completed weeks of gestation for safe institutional delivery. She underwent elective caesarean section for contracted pelvis and delivered a female baby of weight $2.9 \mathrm{~kg}$ with APGAR 7 and 9 at 1 minute and 5 minutes respectively. Anti-hypertensive treatment with Tab. Amlodipine $5 \mathrm{mg}$ once daily was continued. Post-operative pain was managed symptomatically with Injection tramadol. Post-operative period was uneventful. Patient was discharged with advice of continuation of immunosuppressive therapy and contraception.

\section{DISCUSSION}

Pregnancy confers a serious risk in women with moderate to severe kidney disease (defined as serum creatinine $>1.3 \mathrm{mg} / \mathrm{dl}$ and $>1.9 \mathrm{mg} / \mathrm{dl}$ respectively). The patients with advanced chronic renal disease may present with hypothalamic-gonadal dysfunction leading to infertility. Due to rapid restoration of hypothalamic-pituitarygonadal axis within 6 months after renal transplant, it becomes imperative that contraception should be started immediately after transplant in women with childbearing potential. ${ }^{3}$ The best contraception has historically been considered to be barrier methods, but because of potential for contraception failure, the American Society of Transplantation Consensus Conference report recommended that transplant recipients be advised that barrier methods and intrauterine devices are not optimal forms of contraception. Intrauterine devices are not optimal because they require an intact immune system for efficacy. ${ }^{5}$ Progestin-only oral contraceptives as well as estrogen/progestin are probably acceptable for use in this patient population as long as hypertension is well controlled. $^{6-8}$ The best contraceptive agent to use after transplantation depends on considerations, made between the patient and her physician, of the desirability of pregnancy and considerations of the risks and benefits of each contraceptive method. ${ }^{4}$ The optimal timing of pregnancy depends somewhat on individual circumstances of the transplant recipient. Historically, the recommendation was to wait 2 years after successful transplantation. ${ }^{7}$ This recommendation has been replaced by the American Society of Transplantation Consensus
Opinion that as long as graft function is optimal, defined as a serum creatinine $<1.5 \mathrm{mg} / \mathrm{dl}$, with $<500 \mathrm{mg} / 24 \mathrm{~h}$ protein excretion, and no concurrent fetotoxic infections or use of teratogenic or fetotoxic medications, and immunosuppressive dosing is stable at maintenance levels, the patient can safely proceed with the pregnancy. ${ }^{4}$ Given the increasing age of the transplant population, these recommendations might even be liberalized to waiting 6 months after transplantation in specific situations. $^{4,9}$ There have been no specific recommendations for male transplant recipients with regard to post transplantation intervals and fathering a child.

The recommended maintenance immunosuppression in pregnant women is with calcineurin inhibitors (Tacrolimus/Cyclosporine), azathioprine, and low dose prednisone; and it is considered safe. Sirolimus and Mycophenolate mofetil should be stopped 6 weeks prior to conception. . $^{4,9,10}$

In our case all immunosuppressive drugs continued except Mycophenolate mofetil which was stopped six months before planning for pregnancy. These drug levels are frequently checked during pregnancy for dose titration.

Among kidney transplant recipients, studies report that approximately $35 \%$ of pregnancies do not progress beyond the 1 st trimester due to spontaneous or therapeutic abortion and that overall success rate is > $90 \%$ after the 1 st trimester. ${ }^{11}$ Most common maternal complication is hypertension. The prevalence of hypertension in pregnant renal transplant patients (up to $73 \%$ in the National Transplantation Registry (NTPR), $50 \%$ in Asia). ${ }^{12-14}$ Alpha Methyl-dopa is considered the drug of choice because of its well documented safety and lack of teratogenicity. ${ }^{15}$ Other antihypertensive agents that are considered acceptable include Labetolol, Nifedipine, and Thiazide diuretics. Maternal renal transplant patients with hypertension are at increased risk for development of superimposed preeclampsia, with an incidence of 15 to $25 \%$ compared with $5 \%$ of normotensive pregnancies. ${ }^{16}$ Other comorbidities to be considered in the maternal transplant recipient include gestational diabetes, anemia, and infections such as urinary tract infections. ${ }^{17,18}$ Urinary tract infections occur in up to $42 \%$ of pregnant renal transplant patients, although pyelonephritis is rare. ${ }^{18}$ The rates of preterm delivery have been reported to be approximately $50 \%$ in the US and European and UK registries and even higher $(64 \%)$ in recent center reports. ${ }^{19,20}$ Most deliveries occur early because of maternal and/or fetal compromise, rather than spontaneous preterm labor. ${ }^{21}$ Transplant recipients are at high risk for premature rupture of membranes, which also contributes to the increased risk for preterm labor, as does pyelonephritis and acute allograft rejection. ${ }^{21}$ Expert consensus opinion has been that unless there is an obstetric reason to indicate cesarean delivery, vaginal delivery is preferred. $^{4}$ Immunosuppressive 
medication exposure may continue after birth if the mother opts to breastfeed. Most physicians advise against breastfeeding, although this has not persuaded all new mothers with kidney transplants. ${ }^{4}$ Studies are needed on pharmacokinetics and transfer of immunosuppressive medications to breast milk. Until these studies are available, expert consensus is that breastfeeding need not be seen as absolutely contraindicated. ${ }^{4}$

\section{CONCLUSION}

To conclude, post-renal transplantation pregnancy is quite safe with an immunosuppressive regimen with good outcomes when renal function is adequate, without proteinuria, and the blood pressure is under control before pregnancy. However, post-renal transplantation pregnancy should still be considered as a high-risk pregnancy to both mother and foetus, so that it should be approached in a multidisciplinary way. With close medical and obstetric follow up, successful outcome for both mother and infant is possible.

\section{ACKNOWLEDGMENTS}

Author would like to thank to the patient and Department of Obstetrics and Gynecology, Nephrology, Urology of NRI Medical College and General Hospital for allowing us to conduct this study.

Funding: No funding sources

Conflict of interest: None declared

Ethical approval: Not required

\section{REFERENCES}

1. Fuchs KM, Coustan DR. Immunosuppressant therapy in pregnant organ transplant recipients. Semin Perinatol. 2007 Dec 1:31(6):363-71.

2. Ostensen M, Khamashta M, Lockshin M, Parke A, Brucato A, Carp H, et al. Anti-inflammatory and immunosuppressive drugs and reproduction. Arthritis Res Ther. 2006:8(3):209.

3. Guazzelli CA, Torloni MR, Sanches TF, Barbieri M, Pestana JO. Contraceptive counseling and use among 197 female kidney transplant recipients. Transplantation. 2008 Sep 15;86(5):669-72.

4. McKay DB, Josephson MA. Reproduction and transplantation: report on the AST Consensus conference on reproductive issues and transplantation. Am J Transplantation. 2005 Jul;5(7):1592-9.

5. Zerner J, Doil KL, Drewry J, Leeber DA: Intrauterine contraceptive device failures in renal transplant patients. J Reprod Med. 1981 Feb ;26(2):99-102.

6. Lessan-Pezeshki M, Ghazizadeh S, Khatami MR, Mahdavi M, Razeghi E, Seifi S, et al: Fertility and contraceptive issues after kidney transplantation in women. Transplant Proc. 2004 Jun 1;36(5):1405-6.

7. Davison JM, Bailey DJ: Pregnancy following renal transplantation. J Obstet Gynaecol Res. 2003;29:227 -33 .

8. Mastrobattista JM, Katz AR: Pregnancy after organ transplant. Obstet Gynecol Clin North Am. 2004;31 :415-28.

9. Josephson MA, McKay DB: Considerations in the medical management of pregnancy in transplant recipients. Adv Chronic Kidney Dis. 2007 Apr 1;14(4):156-67.

10. EBPG expert group in renal transplantation: European best practice guidelines for renal transplantation. Section IV: Long-term management of the transplant recipient. IV. 10. Pregnancy in renal transplant recipients. Nephrol Dial Transplant. 2002;17(4):50-5.

11. Stratta P, Canavese C, Giacchino F, Mesiano P, Quaglia M, Rossetti M. Pregnancy in kidney transplantation: satisfactory outcomes and harsh realities. J Nephrol. 2003;16(6):792-806.

12. Sibanda N, Briggs JD, Davison JM, Johnson RJ, Rudge CJ: Pregnancy after organ transplantation: A report from the UK Transplant pregnancy registry. Transplantation. 2007 May 27;83(10):1301-7.

13. Armenti VT, Moritz MJ, Davison JM: Pregnancy in female pediatric solid organ transplant recipients. Pediatr Clin North Am. 2003 Dec;50(6):1543-60.

14. Armenti VT, Moritz MJ, Cardonick EH, Davison JM: Immunosuppression in pregnancy: Choices for infant and maternal health. Drugs. 2002 Nov $1 ; 62(16): 2361-75$.

15. Umans JG: Medications during pregnancy: Antihypertensives and immunosuppressives. Adv Chronic Kidney Dis. 2007 Apr 1;14(2):191-8.

16. Podymow T, August P: Hypertension in pregnancy. Adv Chronic Kidney Dis. 2007 Apr 1;14(2):178-90.

17. Yassaee F, Moshiri F: Pregnancy outcome in kidney transplant patients. Urol J. 2007;4(1):14-7.

18. Oliveira LG, Sass N, Sato JL, Ozaki KS, Medina Pestana JO: Pregnancy after renal transplantation: A five-yr single-center experience. Clin Transplant. 2007 May;21(3):301-4.

19. McKay DB, Josephson MA: Pregnancy in recipients of solid organs: Effects on mother and child. N Engl J Med. 2006 Mar 23;354(12):1281-93.

20. Cruz Lemini MC, Ibargüengoitia OF, Villanueva GMA. Perinatal outcome following renal transplantation. Int J Gynecol Obs. 2007;96(2):76-9.

21. Del Mar Colon M, Hibbard JU: Obstetric considerations in the management of pregnancy in kidney transplant recipients. Adv Chronic Kidney Dis. 2007 Apr 1;14(2):168-77.

Cite this article as: Kodey $\mathrm{P}$, Bahadur BR, Srilatha V, Rao GS, Sowjanya P. Case report of a successful term pregnancy following renal transplantation. Int $\mathbf{J}$ Reprod Contracept Obstet Gynecol 2019;8:3428-30. 